\title{
Validation and Refinement of Soil Test Based Derieved Fertilizer Equation for SRI Rice in Vertisol
}

\author{
Krishna*, L. K. Srivatsava, V. N. Mishra, Neha Padhi, Neeta Rathia and Susma \\ College of Agriculture, Indira Gandhi Krishi Vishwavidyalaya, Raipur, Chhattisgarh, India \\ *Corresponding author
}

\section{A B S T R A C T}

\section{Keywords}

STCR, Rice, SRI, FYM, Vertisol

\section{Article Info}

Accepted:

10 April 2020

Available Online:

10 May 2020
The fertilizer adjustment equations evolved during previous season for the Swarna variety of rice was tested and fertilizer application with organic source (FYM). It was also noticed that fertilizer dose applied based on STCR prescription derived previously to achieve a definite yield target could not be obtained. This may be due to differences in various input use efficiency, nutritional requirement. However, further refinement of the equations was tried using nutrients omission plot technique and basic parameters required for the formulation of the fertilizer equations were confirmed. The amount of nutrient required to produce one quintal of rice grain yield was found to be $1.57 \mathrm{~kg} \mathrm{~N}, 0.30 \mathrm{~kg} \mathrm{P}$ and $1.71 \mathrm{~kg} \mathrm{~K}$. The contribution of fertilizer N, P and $\mathrm{K}$ were estimated as 41.83, 28.37 and 116.21 per cent. Similarly, the contribution of soil test N, P and K were recorded as 33.55, 81.28 and 19.10 percent. The contribution of organic source (FYM) was observed as $13.8 \% \mathrm{~N}, 6.67 \% \mathrm{P}$ and $11.64 \% \mathrm{~K}$. After refinement of the fertilizer prescription equations, it was observed that by calculation with new equation, $\mathrm{N}$ and $\mathrm{P}$ fertilizer requirement at various soil test levels increased over existing equations developed previously. However, the dose of $\mathrm{K}$ fertilizer was lower than existing one. Hence, a new set of N P K doses at different soil test levels were evolved and need to be tested for its suitability under similar soil and crop situation.

\section{Introduction}

Fertilizer is one of the costliest inputs in agriculture and the use of right elements in right amount of fertilizer at right time is fundamental for farm profitability and environmental protection. Soil testing as a diagnostic tool, the value of soil testing both in general and specific terms is to identify soil fertility problems and constraints in an area and to give specific fertilizer recommendation based on soil testing results of a farm holding. 
At the same time a balanced fertilization has to be considered for maintaining soil health for sustainable use because indiscriminate and imbalanced use of fertilizers has already distorted soil fertility and deteriorated soil health in India (Santhi et al., 2011). Soil test based fertilizer recommendations result in efficient fertilizer use and maintenance of soil fertility.

Several approaches have been used for fertilizer recommendation based on chemical soil test so as to attain maximum yield per unit of fertilizer use. Among the various approaches, the soil test crop response (STCR) studies help to generate fertilizer adjustment equations and calibration charts for recommending fertilizers on the basis of soil tests and achieving targeted yield of crops (Ramamoorthy et al., 1967, Singh and Biswas, 2000). The formulation of soil test based fertilizer equations generated for a particular soil type and climatic conditions requires validation for their suitability in similar soil and climatic conditions. If validation is differed more than $\pm 10 \%$ then certain refinement can be done in constant values used in fertilizer equations by adjusting efficiencies of fertilizer, Fertilizer application and yield target chosen can be so manipulated that both high profit from fertilizer investment and maintenance of soil fertility can be achieved (Velayutham, 1979). Targeted yield concept is based on quantitative idea of the fertilizer needs based on yield and nutritional requirement of the crop, per cent contribution of the soil available nutrient and fertilizer applied. This method not only estimates soil test based fertilizer dose but also the level of yield the farmer can achieve with that particular dose. Targeted yield approach also provides scientific basis for balanced fertilization not only between the nutrients from the external sources but also from the external sources. Target yield approach has to be used to formulate fertilizer recommendations across the country (Santhi et al., 2004).

In India rice (Oryza sativa) is the staple food crop for more than two thirds of the population. The slogan "RICE is life" is most appropriate for India as this crop plays a vital role in our national food security and is a means of livelihood for millions of rural households. Over $50 \%$ of the world's population depends on rice as their primary source of energy while the demand for rice keeps growing. It is estimated that rice production should be increased by about $40 \%$ to meet the growing demand by 2030 due to population growth and changing food habits (Khush, 2005). Latest statistics by FAO (2017b) show that global paddy production has grown from around 690 million tons in 2008 to over 750 million tons in 2016and the global area under rice production has grown from around 160 million hectares in 2008 to around 165 million hectares as of 2017.

India produces rice in a large quantity with a production of 104.4 million tonnes and productivity of $2367 \mathrm{~kg} \mathrm{ha}^{-1}$ in 2015-16, grown in an area of 44.1 million hectares. Rice is grown in Chhattisgarh in an area of 37.18 lakh hectares with a production of 66.20 lakh tonnes and productivity of $1780 \mathrm{~kg}$ $\mathrm{ha}^{-1}$ in 2015-16.

\section{Materials and Methods}

A field experiment was conducted at the farm of Indira Gandhi Krishi Vishwavidyalaya, Raipur (Chhattisgarh) The soil of the experimental field comes under the soil order of Vertisol. This soil is locally known as Kanhar. It is clayey in texture with $25.0 \%$ Sand, $26.0 \%$ silt and $49.0 \%$ clay, dark brown to black in color. Some physico-chemical properties of experimental soil were analyzed which found $7.6 \mathrm{pH}$ (1:2.5), $0.18 \mathrm{EC}$ (dSm-1), 35.40 CEC (c mol(p+) kg-1),0. 58 Organic C 
(g kg-1), 198 Available N (kg ha-1), 16 Available P (kg ha-1) and 390 Available K (kg ha-1).The fertilizer materials were used as urea, single supper phosphate and muriate of potash for the source of $\mathrm{N} \mathrm{P}$ and $\mathrm{K}$ nutrient, respectively. Full dose of $\mathrm{P}_{2} \mathrm{O}_{5}$ and $\mathrm{K}_{2} \mathrm{O}$ and $1 / 3$ rd of $\mathrm{N}$ were applied as basal, remaining $2 / 3$ rd of $\mathrm{N}$ applied in two equal splits as top dressing at tillering and panicle initiation stages. Grain and straw samples were analyzed for N, P and K content (Piper, 1966) and total nutrient uptake was computed using grain and straw yield data. Using the data on grain yield, nutrient uptake, pre-sowing soil available nutrients and fertilizer doses applied the basic parameter, viz. nutrient requirement (kg q-1), contribution of nutrients from soil and fertilizer sources were calculated as described by Ramamoorthy et al., (1967). The contribution of nutrients from applied FYM was estimated by relating the yield with fertilizer nutrients and FYM. These parameters were used for the formulation of fertilizer adjustment equations for deriving fertilizer doses and the soil test based fertilizer prescription in the form of ready reckoners for desired yield target of rice.

\section{Experiment design}

The Experimental details are as follows:-

\begin{tabular}{|c|c|}
\hline Location & $\begin{array}{l}\text { : Instructional Farm, } \\
\text { I.G.K.V. Raipur } \\
\text { (C.G.) }\end{array}$ \\
\hline Season & : $\quad$ Kharif, 2017 \\
\hline Soil type & : Vertisol \\
\hline Crop & : $\quad$ Rice \\
\hline Plot Size & $: 16 m^{2}(4 m \times 4 m)$ \\
\hline Row spacing & $: \quad 25 \times 25 \mathrm{~cm}^{2}$ \\
\hline Date of transplanting & $: \quad 15 / 07 / 17$ \\
\hline Date of harvesting & $: \quad 20 / 11 / 17$ \\
\hline Treatment & : Fourteen \\
\hline Replications & : $\quad$ Three \\
\hline Design & : $\quad$ Factorial RBD \\
\hline
\end{tabular}

\section{Treatment details}

\begin{tabular}{|c|c|c|}
\hline S.No. & Treatment & $\begin{array}{l}\text { Fertilizer } \\
\text { Application }\end{array}$ \\
\hline 1. & $\mathrm{~T} 1$ & Control $\left(\mathrm{N}_{0} \mathrm{P}_{0} \mathrm{~K}_{0}\right)$ \\
\hline 2. & $\mathrm{~T} 2$ & $\begin{array}{l}\text { Control }\left(\mathrm{N}_{0} \mathrm{P}_{0} \mathrm{~K}_{0}\right) \\
+\mathrm{FYM}\end{array}$ \\
\hline 3. & T3 & $\mathrm{N}_{120} \mathrm{P}_{60} \mathrm{~K}_{0}$ \\
\hline 4. & $\mathrm{~T} 4$ & $\begin{array}{llll}\mathrm{N}_{120} & \mathrm{P}_{60} & \mathrm{~K}_{0} & + \\
\text { FYM } & & & \\
\end{array}$ \\
\hline 5. & T5 & $\mathrm{N}_{120} \mathrm{P}_{0} \mathrm{~K}_{40}$ \\
\hline 6. & T6 & $\begin{array}{llll}\mathrm{N}_{120} & \mathrm{P}_{0} & \mathrm{~K}_{40} & + \\
\text { FYM } & & \end{array}$ \\
\hline 7. & $\mathrm{~T} 7$ & $\mathrm{~N}_{0} \mathrm{P}_{60} \mathrm{~K}_{40}$ \\
\hline 8. & T8 & $\mathrm{N}_{0} \mathrm{P}_{60} \mathrm{~K}_{40}+\mathrm{FYM}$ \\
\hline 9. & T9 & $\mathrm{N}_{120} \mathrm{P}_{60} \mathrm{~K}_{40}$ \\
\hline 10. & $\mathrm{~T} 10$ & $\begin{array}{llll}\mathrm{N}_{120} & \mathrm{P}_{60} & \mathrm{~K}_{40} & + \\
\text { FYM } & & & \end{array}$ \\
\hline 11. & $\mathrm{~T} 11$ & $\begin{array}{lll}\begin{array}{l}\text { Yield } \\
\text { t/ha }\end{array} & \text { Target } & 8 \\
\end{array}$ \\
\hline 12. & T12 & $\begin{array}{l}\text { Yield Target } 8 \mathrm{t} / \mathrm{ha} \\
+ \text { FYM }\end{array}$ \\
\hline 13. & T13 & $\begin{array}{ll}\begin{array}{l}\text { Yield } \\
\text { t/ha }\end{array} & \\
\end{array}$ \\
\hline 14. & $\mathrm{~T} 14$ & $\begin{array}{l}\text { Yield Target } 10 \\
\text { t/ha + FYM }\end{array}$ \\
\hline
\end{tabular}

\section{Statistical analysis}

The data collected from field observations and those recorded in laboratory were subjected to statistical analysis by standard analysis of variance technique. For significant treatment effects, critical differences were calculated at 5 per cent level of significance.

\section{Results and Discussion}

Results presented in Table. 1 and depicted in Fig.1 show the mean grain yields of rice differed significantly with main effects of treatment $(\mathrm{T})$ however, FYM application $(\mathrm{F})$ and interaction effect (FT) did not show significant variations. Significantly higher grain yield was recorded with the treatment $\mathrm{T}_{7}$ (YT 10 t/ha) followed by $\mathrm{T}_{5}\left(\mathrm{~N}_{120} \mathrm{P}_{60} \mathrm{~K}_{40}\right), \mathrm{T}_{6}$ 
(YT 8 t/ha) and $\mathrm{T}_{2}\left(\mathrm{~N}_{120} \mathrm{P}_{60} \mathrm{~K}_{0}\right)$. STCR based fertilizer dose for yield target of $10 \mathrm{t} / \mathrm{ha}$ received highest yield among all other treatments. Yield performance severely affected when $\mathrm{N}$ and $\mathrm{P}$ were omitted. The grain yield of $\mathrm{N}$ omitted plot showed statistically at par result with that of absolute control thereby indicating that $\mathrm{N}$ is most important limiting nutrient and yield reduced considerably if treatment did not received $\mathrm{N}$ application. Higher yield of rice $(84.50 \mathrm{q} / \mathrm{ha})$ was obtained with the treatment that received higher amount chemical fertilizer coupled with 5 tons of FYM although yield was not as per the yield goal.

It was also noticed that fertilizer dose applied based on STCR prescription derived previously to achieve a definite yield target could not be obtained. This may be due to differences in various input use efficiency, nutritional requirement etc. Application of FYM with chemical fertilizer enhanced the grain yields as compared to chemical fertilizer only. Singh et al., (2009) also concluded that significantly higher grain yield of rice was recorded in the treatment $75 \% \mathrm{RDF}+25 \% \mathrm{~N}$ through FYM, followed by the treatment $50 \%$ $\mathrm{RDF}+50 \% \mathrm{~N}$ through FYM.

The mean straw yield of rice (Table. 2 and Fig.2) showed the similar trend with that of grain yields. Straw yields affected significantly with main effects of treatment (T), while FYM application (F) and Interaction $(\mathrm{TxF})$ had no significant effect on straw yields. As observed in case of straw yields, higher straw yield was recorded with the treatment $\mathrm{T}_{7}$ (YT $10 \mathrm{t} / \mathrm{ha}$ ) followed by $\mathrm{T}_{5}$ $\left(\mathrm{N}_{120} \mathrm{P}_{60} \mathrm{~K}_{40}\right), \mathrm{T}_{2}\left(\mathrm{~N}_{120} \mathrm{P}_{60} \mathrm{~K}_{0}\right), \mathrm{T}_{6}$ (YT $\left.8 \mathrm{t} / \mathrm{ha}\right)$. Among the nutrient omission treatments $\left(\mathrm{T}_{1}\right.$ to $\left.\mathrm{T}_{5}\right)$, application of $\mathrm{RDF}\left(\mathrm{T}_{5}\right)$ performed higher straw yield than that of $\mathrm{T}_{2}$ treatment where $\mathrm{K}$ application was omitted indicating in spite of more accumulation of applied fertilizer $\mathrm{K}$ in its application resulting increase in straw yield but did not contribute to increase in grain yield. Application of FYM also showed higher straw yields over sole application of inorganic fertilizers alone. Straw yield of rice increased with increasing level of fertilizers up to $100 \%$ NPK as reported by Pandey et al., (2009).

Nitrogen uptake by rice (Table.3 and Fig 3) affected significantly with main effects of treatment, FYM application and Interaction of treatment with FYM (TxF). Significantly higher $\mathrm{N}$ uptake was recorded with the treatment $\mathrm{T}_{7}$ (YT $10 \mathrm{t} / \mathrm{ha}$ ) followed by $\mathrm{T}_{6}$ (YT $8 \mathrm{t} / \mathrm{ha}), \mathrm{T}_{5}\left(\mathrm{~N}_{120} \mathrm{P}_{60} \mathrm{~K}_{40}\right), \mathrm{T}_{2}\left(\begin{array}{llll}\mathrm{N}_{120} & \mathrm{P}_{60} & \mathrm{~K}_{0}\end{array}\right)$. STCR based fertilizer dose for yield target of $10 \mathrm{t} / \mathrm{ha}$ received significantly highest $\mathrm{N}$ uptake among all other treatments. Among the nutrient omission treatments $\left(\mathrm{T}_{1}-\mathrm{T}_{5}\right)$, application of RDF (T5) performed significantly higher $\mathrm{N}$ uptake as compared to the treatment $\mathrm{T}_{4}$ where $\mathrm{N}$ was omitted. Total $\mathrm{N}$ uptake was significantly increased with the application of FYM as compared to without FYM. N uptake is the product of content and dry matter yield (grain \& straw). Hence, N uptake performed identical with that of grain yields.

The total $\mathrm{N}$ uptake was significantly increased with increasing doses of $\mathrm{N}$ fertilizer. The $\mathrm{N}$ uptake was increased due to the better availability of nitrogen in soil and their transport to the plant from the soil and availability of nitrogen enhanced by application of higher doses of fertilizer. The per cent increase in $\mathrm{N}$ uptake by different fertilizer and manurial treatment was 93 to $195 \%$ in rice as reported by Bhandari et al., (1992).

Phosphorus uptake by rice (Table.4 and Fig.4) affected significantly with main effects of treatment while FYM application and their interaction effect did not show significant result. Significantly higher $\mathrm{P}$ uptake was 
recorded with the treatment $\mathrm{T}_{5}\left(\mathrm{~N}_{120} \mathrm{P}_{60} \mathrm{~K}_{40}\right)$, followed by $\mathrm{T}_{7}$ (YT $10 \mathrm{t} / \mathrm{ha}$ ), $\mathrm{T}_{6}$ (YT $8 \mathrm{t} / \mathrm{ha}$ ), $\left.\begin{array}{llll}\mathrm{T}_{2} & \left(\mathrm{~N}_{120}\right. & \mathrm{P}_{60} & \mathrm{~K}_{0}\end{array}\right)$. Application of RDF $\left(\mathrm{T}_{5}\right)$ performed significantly higher $\mathrm{P}$ uptake and was at par with that of $\mathrm{T}_{7}$ (YT $\left.10 \mathrm{t} / \mathrm{ha}\right)$. P uptake severely affected when $\mathrm{P}$ was omitted. Total $\mathrm{P}$ uptake was significantly increased with the application of FYM as compared to without FYM.

The phosphorus uptake being a function of biomass production, it was significantly increased due to increase in grain and straw yields along with their concentration in plant and with increasing $\mathrm{N}$ and $\mathrm{P}$ application levels in soil. Plants absorb proportionately more nitrogen and phosphorus from the pool of available with higher dose of application. The uptake of $\mathrm{N}, \mathrm{P}$ and $\mathrm{K}$ in rice was highest when the crop was fertilized with $100 \%$ RDF of NPK (120:60:50 kg N, P2O5 and K2O ha-1) on the basis of soil test. These findings corroborate that of Pal et al., (2009).

Table.1 Average grain yield (q/ha) of rice in relation to different fertilizer treatments with and without FYM application

\begin{tabular}{|l|c|c|c|}
\hline & \multicolumn{3}{|c|}{ Grain yield (q/ha) } \\
\hline Treatments (T) & Without FYM & With FYM & Mean \\
\hline $\mathbf{N}_{\mathbf{0}} \mathbf{P}_{\mathbf{0}} \mathbf{K}_{\mathbf{0}} \mathbf{T}_{\mathbf{1}}$ & 38.00 & 42.44 & 40.22 \\
\hline $\mathbf{N}_{\mathbf{1 2 0}} \mathbf{P}_{\mathbf{6 0}} \mathbf{K}_{\mathbf{0}} \mathbf{T}_{\mathbf{2}}$ & 65.67 & 66.96 & 66.31 \\
\hline $\mathbf{N}_{\mathbf{1 2 0}} \mathbf{P}_{\mathbf{0}} \mathbf{K}_{\mathbf{4 0}} \mathbf{T}_{\mathbf{3}}$ & 58.60 & 62.44 & 60.52 \\
\hline $\mathbf{N}_{\mathbf{0}} \mathbf{P}_{\mathbf{6 0}} \mathbf{K}_{\mathbf{4 0}} \mathbf{T}_{\mathbf{4}}$ & 45.50 & 47.27 & 46.38 \\
\hline $\mathbf{N}_{\mathbf{1 2 0}} \mathbf{P}_{\mathbf{6 0}} \mathbf{K}_{\mathbf{4 0}} \mathbf{T}_{\mathbf{5}}$ & 75.96 & 78.63 & 77.29 \\
\hline YT 8 t/ha $\mathbf{T}_{\mathbf{6}}$ & 68.71 & 70.73 & 69.72 \\
\hline YT 10 t/ha $\mathbf{T}_{\mathbf{7}}$ & 83.79 & 64.21 & 84.51 \\
\hline Mean & 62.31 & 63.56 \\
\hline CD at 5\% level & $\mathbf{T}^{*}=\mathbf{6 . 9 9}, \mathbf{F}=\mathbf{N S}, \mathbf{F T}=\mathbf{N S}$ \\
\hline
\end{tabular}

Table.2 Average straw yield (q/ha) of rice in relation to different fertilizer treatments with and without FYM application

\begin{tabular}{|c|c|c|c|}
\hline \multirow[t]{2}{*}{ Treatment $(\mathbf{T})$} & \multicolumn{3}{|c|}{ Straw yield (q/ha) } \\
\hline & Without FYM & With FYM & Mean \\
\hline $\mathrm{N}_{0} \mathrm{P}_{0} \mathrm{~K}_{0} \mathrm{~T}_{1}$ & 39.11 & 42.93 & 41.02 \\
\hline $\mathbf{N}_{120} P_{60} K_{0} \quad T_{2}$ & 66.23 & 68.10 & 67.16 \\
\hline $\mathrm{N}_{120} \mathrm{P}_{0} \mathrm{~K}_{40} \mathrm{~T}_{3}$ & 60.15 & 61.07 & 60.61 \\
\hline $\mathrm{N}_{0} \mathrm{P}_{60} \mathrm{~K}_{40} \quad \mathbf{T}_{4}$ & 46.40 & 48.57 & 47.48 \\
\hline $\mathrm{N}_{120} \mathrm{P}_{60} \mathrm{~K}_{40} \mathrm{~T}_{5}$ & 77.02 & 80.92 & 78.97 \\
\hline YT $8 \mathrm{t} / \mathrm{ha} \quad \mathrm{T}_{6}$ & 66.01 & 66.97 & 66.49 \\
\hline YT $10 \mathrm{t} / \mathrm{ha} \quad \mathrm{T}_{7}$ & 86.18 & 88.56 & 87.37 \\
\hline Mean & 63.35 & 64.96 & 64.15 \\
\hline CD at $5 \%$ level & \multicolumn{3}{|c|}{$\mathrm{T}^{*}=6.73, \mathrm{~F}=\mathrm{NS}, \mathrm{FT}=\mathrm{NS}$} \\
\hline
\end{tabular}


Table.3 Total $\mathrm{N}$ uptake (kg/ha) by rice (Swarna) in relation to different fertilizer treatments with and without FYM application

\begin{tabular}{|c|c|c|c|}
\hline \multirow{2}{*}{ Treatment $(\mathrm{T})$} & \multicolumn{3}{|c|}{ Total Nitrogen Uptake (kg/ha) } \\
\hline & Without FYM & With FYM & Mean \\
\hline $\mathbf{N}_{0} P_{0} K_{0} T_{1}$ & 66.440 & 67.790 & 67.110 \\
\hline $\mathrm{N}_{120} \mathrm{P}_{60} \mathrm{~K}_{0} \quad \mathrm{~T}_{2}$ & 101.10 & 105.35 & 103.22 \\
\hline $\mathrm{N}_{120} \mathrm{P}_{0} \mathrm{~K}_{40} \mathrm{~T}_{3}$ & 94.690 & 99.860 & 97.270 \\
\hline $\mathrm{N}_{0} \mathrm{P}_{60} \mathrm{~K}_{40} \quad \mathrm{~T}_{4}$ & 67.100 & 71.770 & 69.430 \\
\hline $\mathrm{N}_{120} \mathrm{P}_{60} \mathrm{~K}_{40} \mathrm{~T}_{5}$ & 114.83 & 116.63 & 115.73 \\
\hline YT $8 \mathrm{t} / \mathrm{ha} \quad \mathrm{T}_{6}$ & 116.55 & 115.88 & 116.21 \\
\hline YT $10 \mathrm{t} / \mathrm{ha} \quad \mathrm{T}_{7}$ & 141.49 & 149.09 & 145.29 \\
\hline Mean & 100.31 & 103.76 & 102.03 \\
\hline $\mathrm{CD}_{\text {at }} 5 \%$ level & \multicolumn{3}{|c|}{$\mathrm{T}^{*}=2.22, \mathrm{~F}^{*}=1.19, \mathrm{FT}=3.13$} \\
\hline
\end{tabular}

Table.4 Total P uptake (kg/ha) by rice (Swarna) in relation to different fertilizer treatments with and without FYM application

\begin{tabular}{|c|c|c|c|}
\hline \multirow[b]{2}{*}{ Treatment $(\mathbf{T})$} & \multirow[b]{2}{*}{ Without FYM } & \multicolumn{2}{|c|}{ Total Phosphorus uptake (Kg/ha) } \\
\hline & & With FYM & Mean \\
\hline $\mathbf{N}_{0} P_{0} K_{0} T_{1}$ & 13.00 & 13.30 & 13.15 \\
\hline $\mathbf{N}_{120} P_{60} K_{0} \quad T_{2}$ & 16.86 & 18.23 & 17.54 \\
\hline $\mathrm{N}_{120} \mathrm{P}_{0} \mathrm{~K}_{40} \mathrm{~T}_{3}$ & 16.20 & 17.07 & 16.63 \\
\hline $\mathrm{N}_{0} \mathrm{P}_{60} \mathrm{~K}_{40} \quad \mathrm{~T}_{4}$ & 11.62 & 12.51 & 12.06 \\
\hline $\mathrm{N}_{120} \mathrm{P}_{60} \mathrm{~K}_{40} \mathrm{~T}_{5}$ & 28.14 & 30.03 & 29.08 \\
\hline YT $8 \mathrm{t} / \mathrm{ha} \quad \mathrm{T}_{6}$ & 24.21 & 25.55 & 24.88 \\
\hline YT 10 t/ha T $_{7}$ & 27.71 & 28.55 & 28.13 \\
\hline Mean & 19.79 & 20.62 & 20.21 \\
\hline CD at $5 \%$ level & \multicolumn{3}{|c|}{$\mathrm{T}^{*}=0.6, \mathrm{~F}=\mathrm{NS}, \mathrm{FT}=\mathrm{NS}$} \\
\hline
\end{tabular}


Table.5 Total K uptake (kg/ha) by rice (Swarna) in relation to different fertilizer treatments with and without FYM application

\begin{tabular}{|c|c|c|c|}
\hline \multirow[t]{2}{*}{ Treatment (T) } & \multicolumn{3}{|c|}{ Total K Uptake (kg/ha) } \\
\hline & Without FYM & With FYM & Mean \\
\hline $\mathrm{N}_{0} \mathrm{P}_{0} \mathrm{~K}_{0} \mathrm{~T}_{1}$ & 74.490 & 75.330 & 74.910 \\
\hline $\mathbf{N}_{120} P_{60} K_{0} \quad T_{2}$ & 106.87 & 112.53 & 109.70 \\
\hline $\mathrm{N}_{120} \mathrm{P}_{0} \mathrm{~K}_{40} \mathrm{~T}_{3}$ & 96.180 & 104.02 & 100.10 \\
\hline $\mathrm{N}_{0} \mathrm{P}_{60} \mathrm{~K}_{40} \quad \mathrm{~T}_{4}$ & 82.620 & 87.120 & 84.870 \\
\hline $\mathrm{N}_{120} \mathrm{P}_{60} \mathrm{~K}_{40} \mathrm{~T}_{5}$ & 114.75 & 120.92 & 117.83 \\
\hline YT $8 \mathrm{t} / \mathrm{ha} \quad \mathrm{T}_{6}$ & 116.90 & 127.22 & 122.06 \\
\hline YT $10 \mathrm{t} / \mathrm{ha} \quad \mathrm{T}_{7}$ & 142.39 & 148.10 & 145.24 \\
\hline Mean & 107.17 & 108.45 & 116.38 \\
\hline CD at 5\% level & $T^{*}=1.7$ & $95, \mathrm{FT}=2.5$ & \\
\hline
\end{tabular}

Estimation of basic parameters based on the nutrient omission plot technique

Table.6 Nutrient requirement of rice

\begin{tabular}{|c|c|c|}
\hline \multirow{2}{*}{ Nutrient } & \multicolumn{2}{|c|}{ Nutrient requirement $\left(\mathbf{k g ~ q}^{-\mathbf{1}}\right)$ of rice (Swarna) } \\
\cline { 2 - 3 } & 2016 & 2017 \\
\hline $\mathbf{N}$ & 1.54 & 1.57 \\
\hline $\mathbf{P}$ & 0.28 & 0.30 \\
\hline $\mathbf{K}$ & 1.70 & 1.71 \\
\hline
\end{tabular}

Table.7 Efficiencies of fertilizer, soil test and FYM

\begin{tabular}{|c|c|c|c|c|c|c|}
\hline Nutrient & \multicolumn{2}{|c|}{$\begin{array}{c}\text { Fertilizer efficiency } \\
(\mathbf{\%})\end{array}$} & \multicolumn{2}{|c|}{$\begin{array}{c}\text { Soil test } \\
\text { Efficiency } \\
(\mathbf{\%})\end{array}$} & \multicolumn{2}{|c|}{$\begin{array}{c}\text { FYM } \\
\text { Efficiency } \\
(\boldsymbol{\%})\end{array}$} \\
\hline & $\mathbf{2 0 1 6}$ & $\mathbf{2 0 1 7}$ & $\mathbf{2 0 1 6}$ & $\mathbf{2 0 1 7}$ & $\mathbf{2 0 1 6}$ & $\mathbf{2 0 1 7}$ \\
\hline $\mathbf{N}$ & 40.17 & 41.83 & 35.02 & 33.55 & 18.41 & 13.8 \\
\hline $\mathbf{P}$ & 28.17 & 28.37 & 82.55 & 81.28 & 6.27 & 7.07 \\
\hline $\mathbf{K}$ & 102.2 & 116.1 & 17.24 & 19.10 & 10.79 & 12.5 \\
\hline
\end{tabular}


Table.8 Fertilizer adjustment equation derived for rice cv. Swarna

$$
\begin{array}{|l|l|}
\hline \text { Nutrient management strategy } & \text { Fertilizer adjustment equation } \\
\hline \text { STCR-IPNS } & \mathrm{FN}=3.74 \mathrm{Y}-0.80 \mathrm{SN}-0.33 \mathrm{FYM} \\
\cline { 2 - 2 } & \mathrm{FP}=1.06 \mathrm{Y}-2.86 \mathrm{SP}-0.25 \mathrm{FYM} \\
\cline { 2 - 2 } & \mathrm{FK}=1.47 \mathrm{Y}-0.16 \mathrm{SK}-0.11 \mathrm{FYM} \\
\hline
\end{array}
$$

\begin{tabular}{|c|c|c|c|c|c|c|c|c|}
\hline \multirow{2}{*}{\multicolumn{3}{|c|}{ Soil test value (kg/ha) }} & \multicolumn{6}{|c|}{ Yield target of rice $(q / h a)$} \\
\hline & & & \multicolumn{3}{|c|}{ Existing equation } & \multicolumn{3}{|c|}{ New equation } \\
\hline $\mathbf{N}$ & $\mathbf{P}$ & $\mathbf{K}$ & $\mathbf{F N}$ & $\mathbf{F P}$ & FK & FN & FP & FK \\
\hline 150 & 4 & 200 & 169 & 67 & 93 & 178 & 72 & 85 \\
\hline 175 & 6 & 225 & 147 & 61 & 88 & 158 & 66 & 81 \\
\hline 200 & 8 & 250 & 124 & 55 & 84 & 138 & 61 & 77 \\
\hline 225 & 10 & 275 & 102 & 49 & 80 & 118 & 55 & 73 \\
\hline 250 & 12 & 300 & 80 & 43 & 76 & 98 & 49 & 69 \\
\hline 275 & 14 & 325 & 58 & 37 & 71 & 78 & 44 & 65 \\
\hline 300 & 16 & 350 & 35 & 31 & 67 & 58 & 38 & 61 \\
\hline 325 & 18 & 375 & 13 & 25 & 63 & 38 & 32 & 57 \\
\hline 350 & 20 & 400 & 13 & 19 & 59 & 18 & 26 & 53 \\
\hline 375 & 22 & 425 & 13 & 13 & 54 & 18 & 21 & 49 \\
\hline 400 & 24 & 450 & 13 & 7 & 50 & 18 & 15 & 45 \\
\hline
\end{tabular}

Table.9 Comparison of soil test based fertilizer recommendations by existing equation and new developed equation for rice to achieve $8 \mathrm{t}$ yield target in Vertisols with $5 \mathrm{t}$ of FYM

Where, FN, FP and FK are fertilizer $\mathrm{N}, \mathrm{P}_{2} \mathrm{O}_{5}$ and $\mathrm{K}_{2} \mathrm{O}\left(\mathrm{Kg} \mathrm{ha}^{-1}\right)$ respectively. SN, SP and SK are soil test values $\left(\mathrm{kg} \mathrm{ha}^{-1}\right.$ ) for $\mathrm{KMnO}_{4}$ - N, Olsen's $\mathrm{P}$ and ammonium acetate extractable $\mathrm{K}$ 

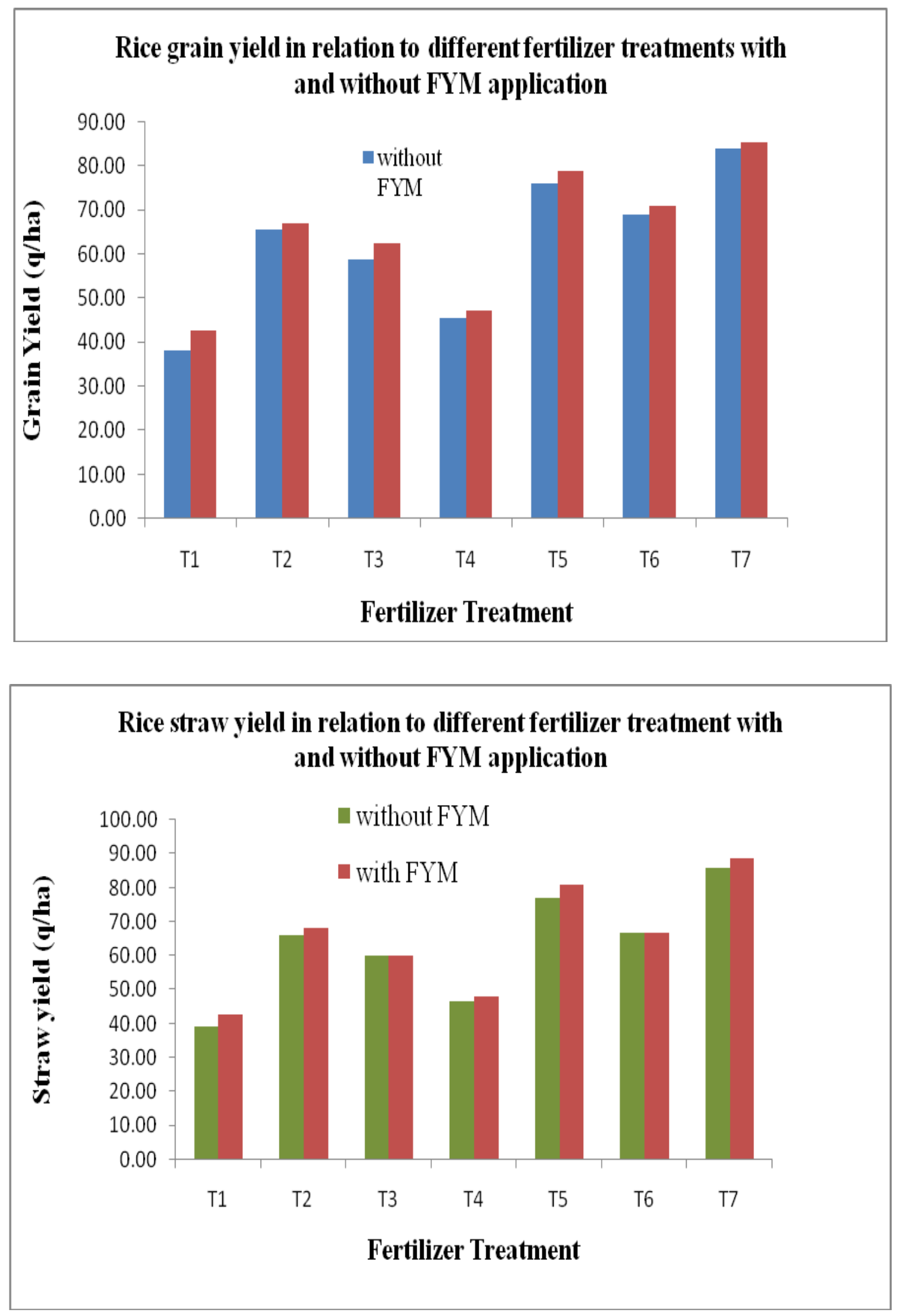

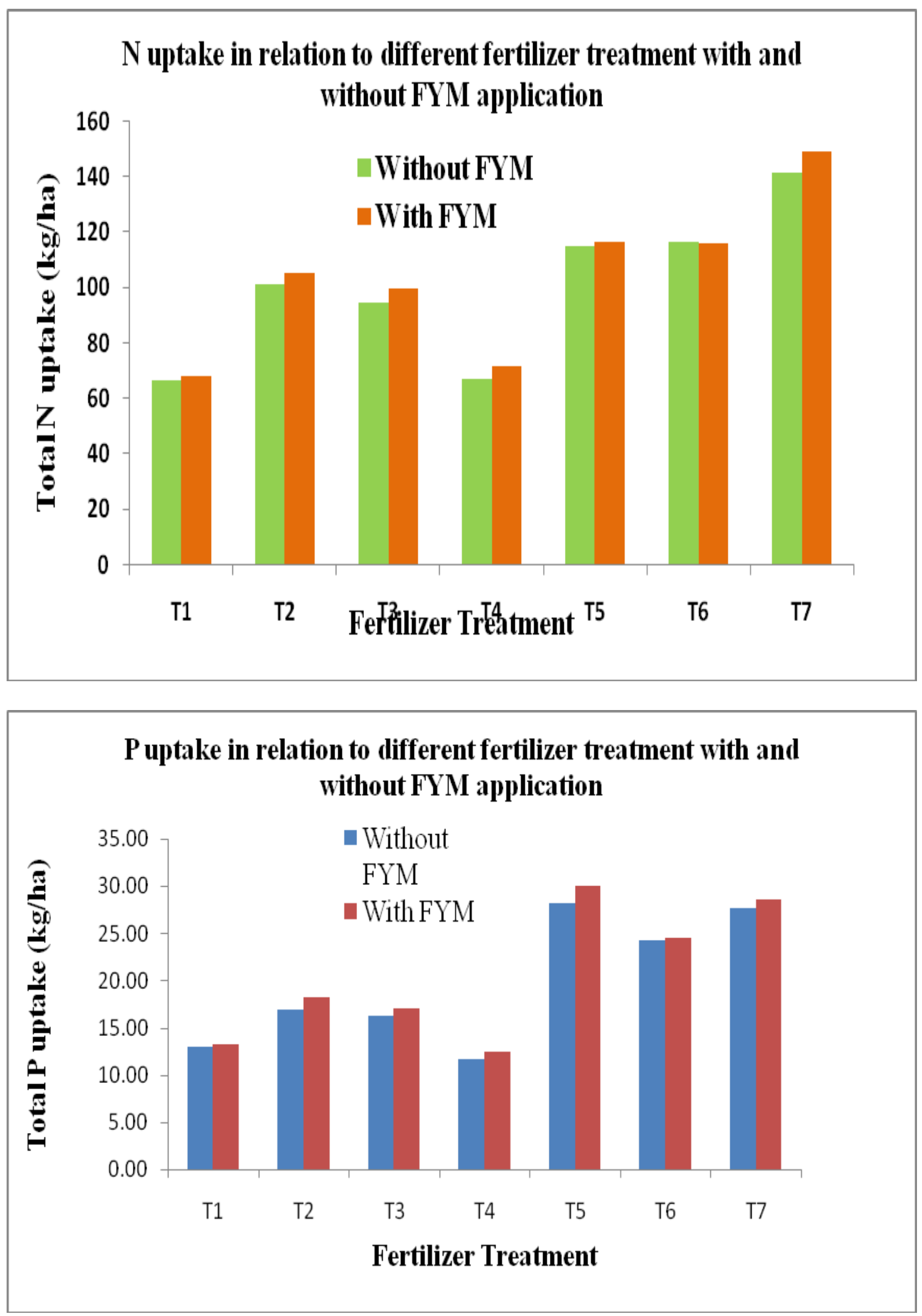


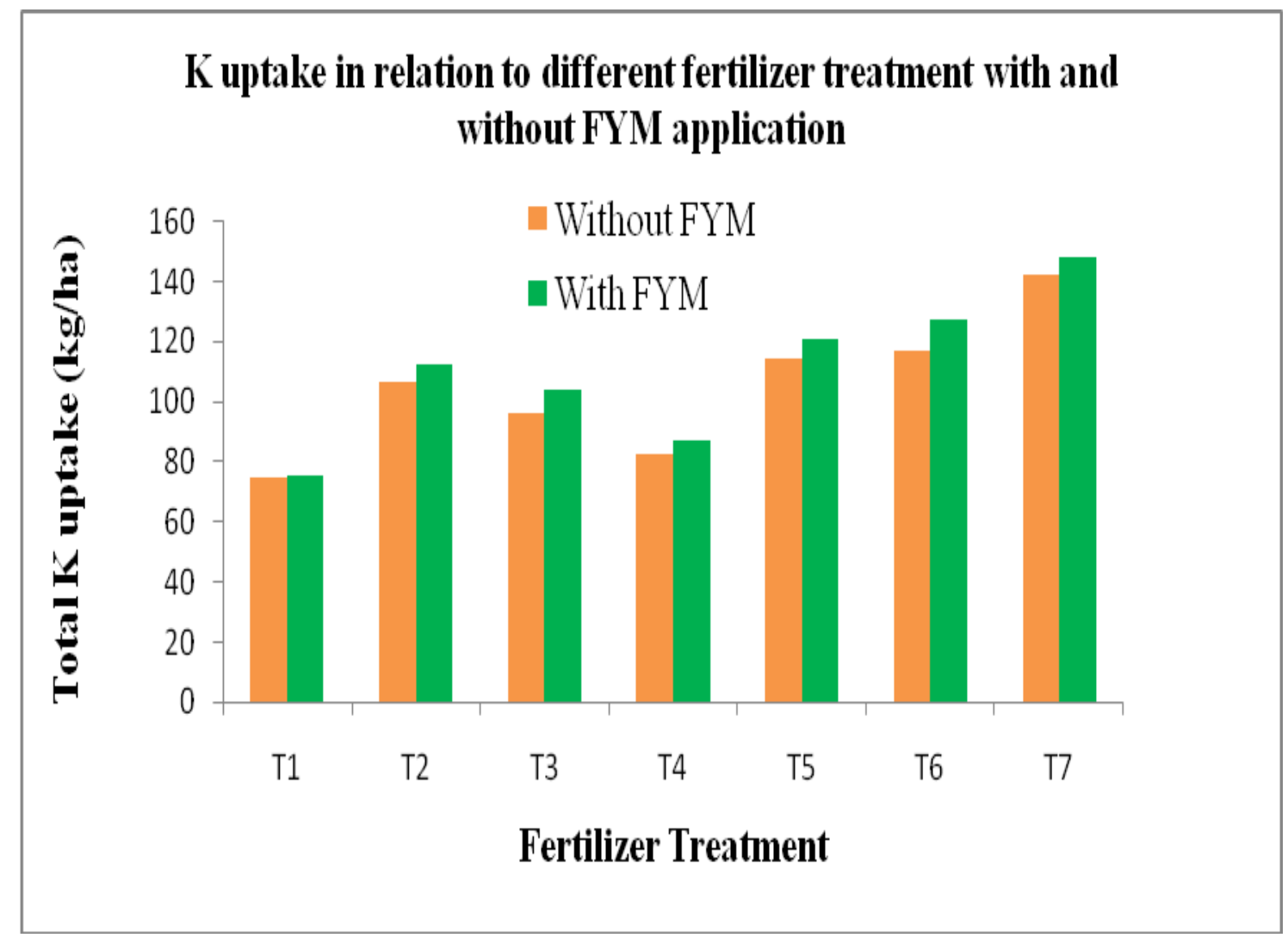

Comparison of soil test based fertilizer recommendations by existing equation and new developed equation for rice to achieve 8.0 Ton yield target in Vertisol

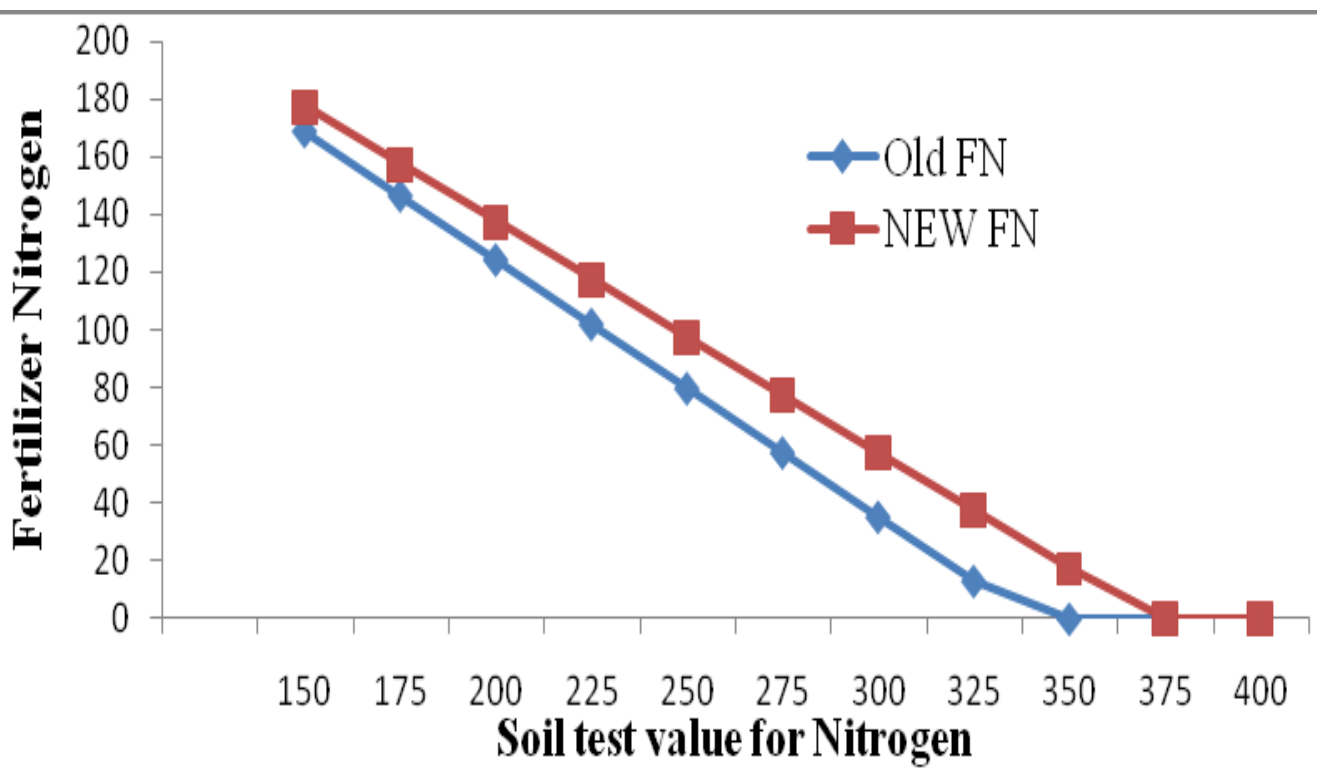



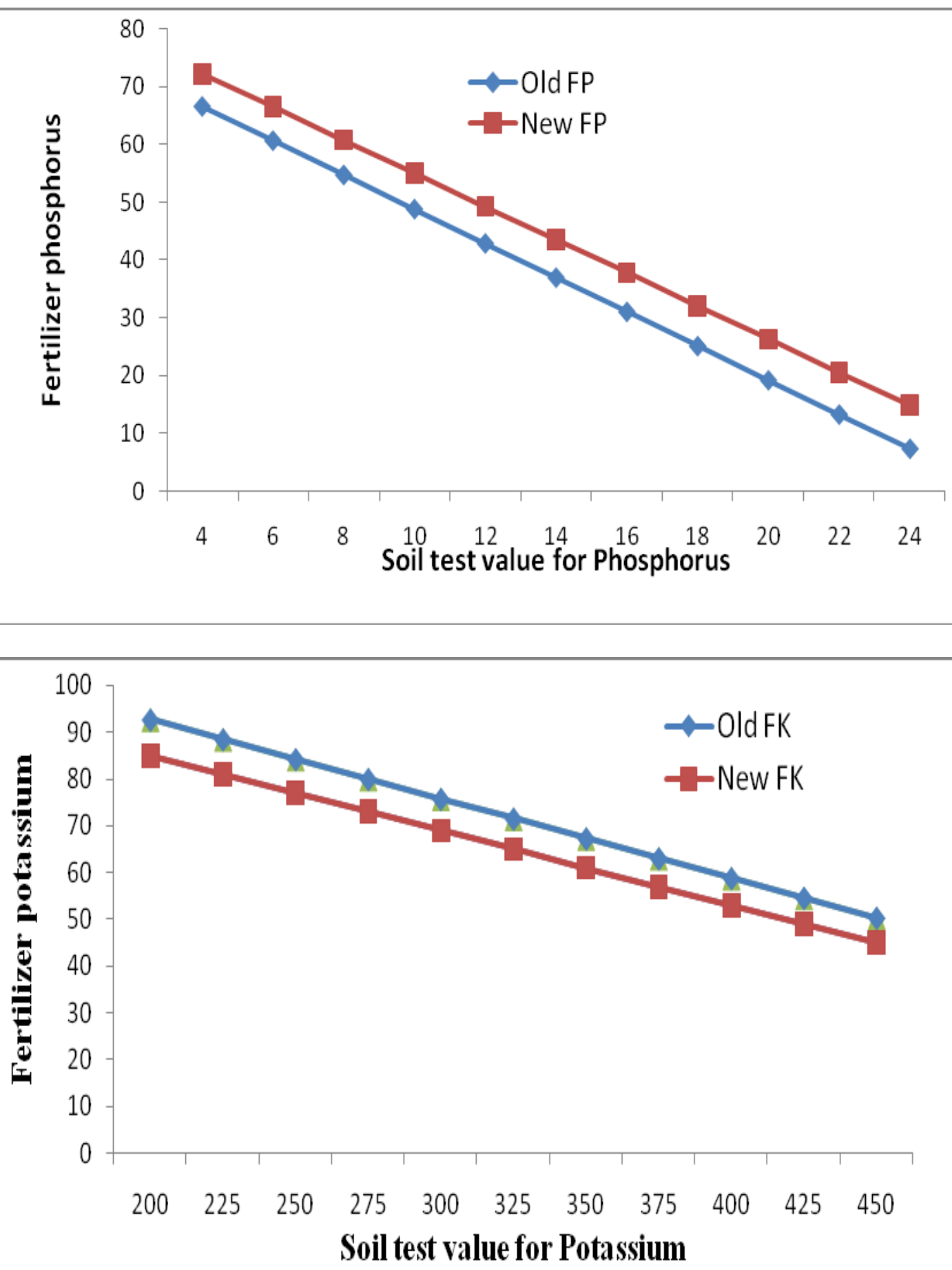

Potassium uptake by rice (Table.5 and Fig.5) affected significantly with main effects of treatment and FYM application. Interaction of treatment with FYM (TxF) had significant effect on K uptake. Significantly higher K uptake was recorded with the treatment $T_{7}$ (YT $10 \mathrm{t} / \mathrm{ha}$ ) followed by $\mathrm{T}_{6}(\mathrm{YT} 8 \mathrm{t} / \mathrm{ha}), \mathrm{T}_{5}$
$\left(\mathrm{N}_{120} \mathrm{P}_{60} \mathrm{~K}_{40}\right)$ and $\mathrm{T}_{2}\left(\mathrm{~N}_{120} \mathrm{P}_{60} \mathrm{~K}_{0}\right)$ and $\mathrm{T}_{3}\left(\mathrm{~N}_{120}\right.$ $\left.\mathrm{P}_{0} \mathrm{~K}_{40}\right)$. STCR based fertilizer dose for yield target of $10 \mathrm{t} /$ ha received significantly highest K uptake.

Total K uptake was significantly increased with the application of FYM over its no 
application. Pandey et al., (2009) reported that potassium uptake from $49.782 .6 \mathrm{~kg}$ ha-1 by rice increased with increasing levels of NPK from 0 to $150 \%$. Similarly, Datta and Singh (2010) also reported that with the application of 10 tonnes cattle manure ha-1, nutrient uptake exhibited 1.38-2.36 and 1.762.60 times increased in rice-green gram and rice-field pea cropping systems, respectively.

\section{Derivation of fertilizer prescriptions equation based on basic parameters evolved during current season experiment}

The derivation of new fertilizer equations using the basic parameters like nutrient requirement, efficiencies of fertilizer, soil and organic source were developed for rice as elaborated below

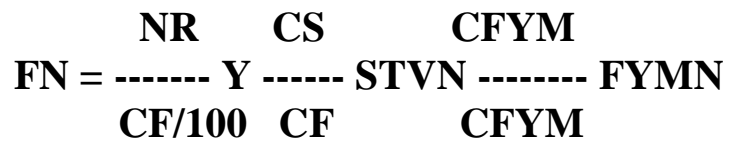

Where, $\mathrm{FN}$ is fertilizer nutrients $(\mathrm{N}, \mathrm{P}$ and $\mathrm{K}$ $\mathrm{kg} / \mathrm{ha}$ ), NR - nutrient requirement of $\mathrm{N}, \mathrm{P}$ and $\mathrm{K}(\mathrm{kg} / \mathrm{q})$; $\mathrm{CS}, \mathrm{CF}$ and CFYM - percentage contributions (efficiency) of $\mathrm{N} P \quad \& \quad \mathrm{~K}$ nutrients from soil, fertilizer and farmyard manure, respectively; STVN is soil test value for available $\mathrm{N}, \mathrm{P}$ and $\mathrm{K}(\mathrm{kg} / \mathrm{ha})$; $\mathrm{FYM}$ is Farm Yard Manure, Y - yield (q/ha) of the test crop.

\section{Ready reckoners for fertilizer recommendations of rice}

The comparative ready reckoners table was prepared based on the equations derived previously for rice with existing equation and new currently developed equations with five tonnes of FYM application (Table.6).It was noticed that by calculation with new equation, $\mathrm{N}$ and $\mathrm{P}$ fertilizer requirement at various soil test levels increased over existing equations developed previously. However, the doses of
$\mathrm{K}$ fertilizer were lower than existing one. Hence, a new set of N P K doses at different soil test levels were evolved and need to be tested for its suitability under similar soil and crop situation. It was remarkably noticed that yield targets of 8 and 10 t/ha were not achieved with existing equation derived during previous season with SRI rice. However, fertilizer doses with new equations have estimated higher amount of $\mathrm{N}$ and $\mathrm{P}$ which might fulfill the nutrient requirement for higher yield target although this needs field validation in the next crop season. It is evident that the fertilizer requirements decreased with increase in soil test values and differences between two equations resulted higher at increasing soil test levels particularly for $\mathrm{N}$ fertilizer. This may be due to lower contribution of $\mathrm{N}$ from soil and FYM sources.

Thus the targeted yield approach of fertilizer recommendation ensures nutrient balancing to suit the situations involving different yield goals, soil fertility and resources of the farmer (Dev et al., 1985). The existing equations derived during 2016 for Swarnavariety of rice were refined by the estimation of new basic parameters as mentioned above. The new equations have been compared with that of existing one and can be said superior over existing after validation.

\section{References}

Bhandari, A. L., Sood. A., Sharma, K. N. and Rana, D. S. 1992. Integrated nutrient management in a rice-wheat system. J. Indian Soc. Soil. Sci. 40 (4): 742-747.

Datta, M. and Singh, N. P. 2010. Nutrient management in rice-based cropping systems as influenced by applying Cattle Manure alone or in combination with fertilizers in upland acid soils of Tripura. J. Indian Soc. Soil. Sci. 58 (1) 94-98. 
Dev, G., Dillion, N. S., Brar, J. S. and Vig, A.C. 1985. Soil test based yield targets for wheat and rice-cropping system. Fert. News. 30 (5): 42-50.

FAO.2017b.Rice Market Moniter (RMM) [online]. Available http://www.fao.org/economic/est/public ations/rice-publications/rice-marketmonitorrmm/en/ [Accessed 8.6.2017].

Khush, G. S. 2005. What it will take to Feed 5.0 Billion Rice consumers in 2030. An International Journal on Molecular Biology, Molecular Genetics and Biochemistry, 59, 1-6.

Pal, S.; Banerjee, H., Basu, B. and Maiti, S. 2009. Studies on nutrient management practice in rice-rice crop sequence under new alluvial zone of West Bengal. Oryza. 45 (10): 125-128.

Pandey, A. K., Kumar Vipin and Kumar Rajesh 2009. Effect of long-term organic and inorganic nutrients on transplanted rice under rice-wheat cropping system. J. Oryza. 46: (3): 209212.

Ramamoorthy, B., Narasimhan, R. L. and Dinesh, R.S. 1967. Fertilizer application for specific yield targets of Sonara-64. Indian Farming, 17 (5): 43-45.

Santhi, R., Natesan, R., Andi, K. and Selvakumari, G. 2004. Soil test based fertilizer recommendation for sunflower. (Heliathus annus L). in Inceptisols of Tamilnadu. J. Oil Seed Res. 21 (1): 78-81.

Santhi et al., 2011. Targeted yield based fertilizer prescriptions for autumn rice (Oryza sativa L.) in inceptisols of Assam, India. Indian J. Agric. Res., 49 (5): 437-441.

Velayutham, M. 1979. Fertilizer recommendation based on targeted yield concept: problem and prospects. Fert News. 24 (9): 12-17.

\section{How to cite this article:}

Krishna, L. K. Srivatsava, V. N. Mishra, Neha Padhi, Neeta Rathia and Susma. 2020. Validation and Refinement of Soil Test Based Derieved Fertilizer Equation for SRI Rice in Vertisol. Int.J.Curr.Microbiol.App.Sci. 9(05): 1485-1498. doi: https://doi.org/10.20546/ijcmas.2020.905.169 